\title{
A Versatile Rocket Engine Hot Gas Facility
}

NASA-CR-195339

19940029625

James M. Green

NYMA, Inc.

Engineering Services Division

Brook Park, Ohio

June 1994

Prepared for

Lewis Research Center

Under Contract NAS3-25266
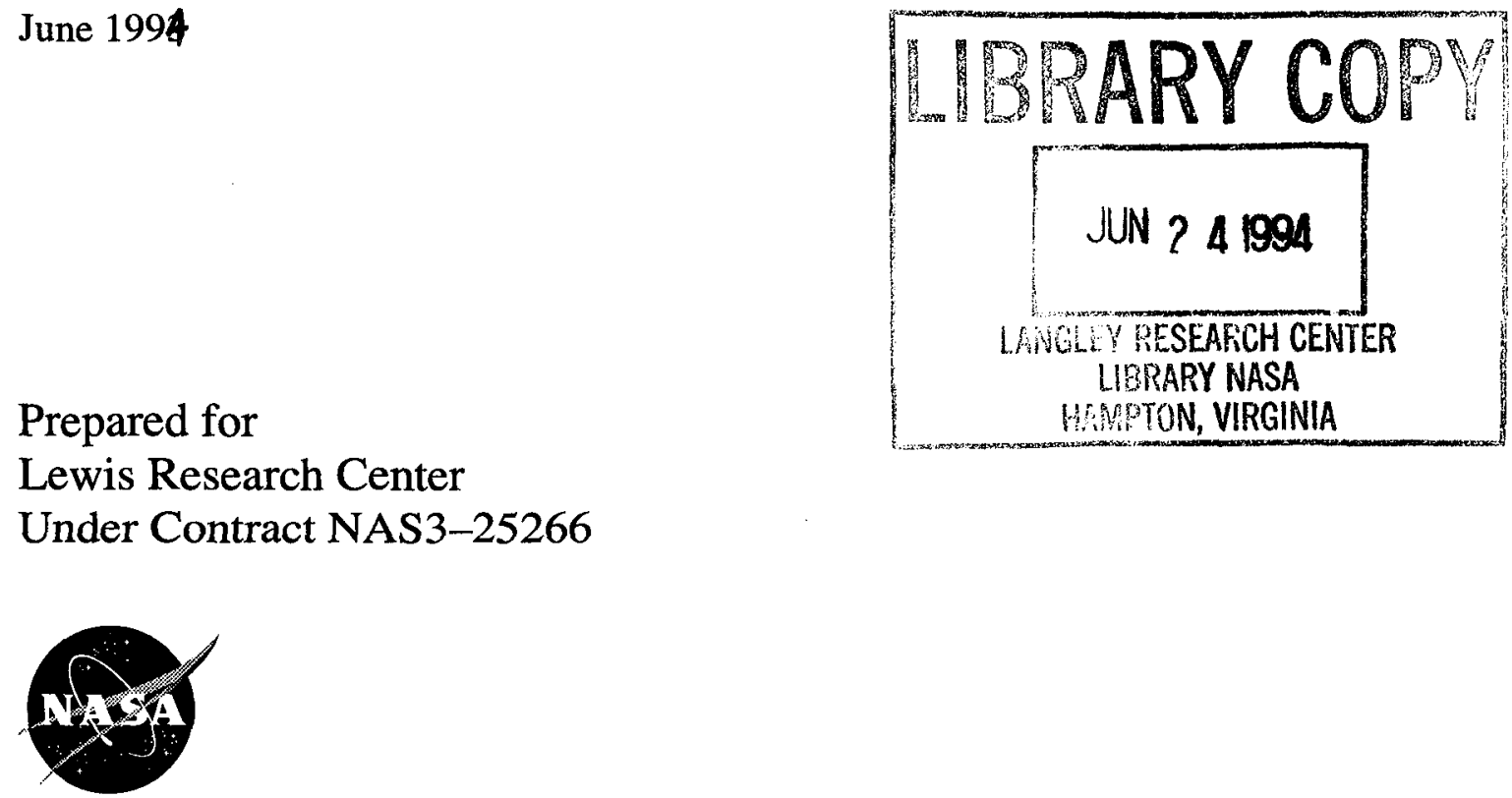

National Aeronautics and

Space Administration 


\title{
A Versatile Rocket Engine Hot Gas Facility
}

\author{
James M. Green \\ NYMA, Inc. \\ Engineering Services Division \\ Brook Park, Ohio 44142
}

\begin{abstract}
The capabilities of a versatile rocket engine facility, located in the Rocket Laboratory at the NASA Lewis Research Center, are presented. The gaseous hydrogen/oxygen facility can be used for thermal shock and hot gas testing of materials and structures as well as rocket propulsion testing. Testing over a wide range of operating conditions in both fuel and oxygen rich regimes can be conducted, with cooled or uncooled test specimens. The size and location of the test cell provide the ability to conduct large amounts of testing in short time periods with rapid turnaround between programs.
\end{abstract}

\section{INTRODUCTION}

The Rocket Laboratory at the NASA Lewis Research Center consists of a number of small test facilities designed for rocket propulsion and related research. The small size and workhorse nature of the facilities in the Rocket Lab, plus the excellent technical support crew, team up to provide high data output at low cost, with rapid turnaround times between programs. Some of the other facilities in the Rocket Lab are described in Refs. 1 to 4.

Test Cell 22 of the Rocket Laboratory (RL22), also known as the Hot Gas Facility or Thermal Shock Test Rig, is a versatile facility capable of supporting many different types of research programs.

The gaseous hydrogen/oxygen $\left(\mathrm{H}_{2} / \mathrm{O}_{2}\right)$ rocket combustor in the test facility is used to generate high temperature, high heat flux, $\mathrm{H}_{2}$ or $\mathrm{O}_{2}$ rich hot gas environments over a wide range of operating conditions and test times. Gas temperatures from approximately 1000 to $3000^{\circ} \mathrm{C}\left(1832\right.$ to $\left.5432{ }^{\circ} \mathrm{F}\right)$ can be delivered, with heat flux at the nozzle exit as high as $5000 \mathrm{~W} /$ $\mathrm{cm}^{2}$ (4406 BTU/ft ${ }^{2}$ ). Test specimens are generally mounted in the exhaust plane of the engine and subjected to the high temperature gas.
RL22 has supported a diverse group of materials and structures projects, working with in-house researchers as well as outside industry. For example, two programs supporting Earth-to-orbit technology development have been tested in RL22. Ceramic Matrix Composite (CMC) materials testing is an ongoing program to verify the thermal shock durability and coating performance of different $\mathrm{CMC}$ coupons and turbine blades. ${ }^{5}$ Thin Film Thermocouples (TFTC) were tested to develop successful bonding techniques to adhere the TFTC material to an alloy in a hot gas, erosive environment. ${ }^{6}$

Testing was also conducted in the area of hypersonic structures research for the National Aerospace Plane (NASP) program, in the areas of seals and leading edges. ${ }^{7}$ Transpiration cooled seals, cooled with chilled $\mathrm{H}_{2}$ gas, were tested to determine cooling efficiency and improve the manufacturing techniques of the seals. Leading edge coatings and structures were tested in both $\mathrm{H}_{2}$ and $\mathrm{O}_{2}$ rich environments to determine the performance of the leading edge coating and the structural design.

While RL22 has mainly been utilized for materials and structures testing, different hardware can also be mounted on the test stand for conducting rocket propulsion research.

This paper will present an overview of the facility, the capabilities of the mechanical and electronic systems, and a description of the hardware used for many of the research programs in the facility.

\section{FACILITY OVERVIEW}

An aerial view of the Rocket Lab, shown in Fig. 1, shows the location of RL22, along with the $\mathrm{H}_{2}$ and $\mathrm{O}_{2}$ tube trailers and the exhaust system for the cell. The propellant trailers are located behind earthen mounds, and are shared with the adjacent facility, RL21. Only one of the facilities can run at a time, but the two are routinely operated on an every-other-day basis. The exhaust system was originally built to scrub hazard- 


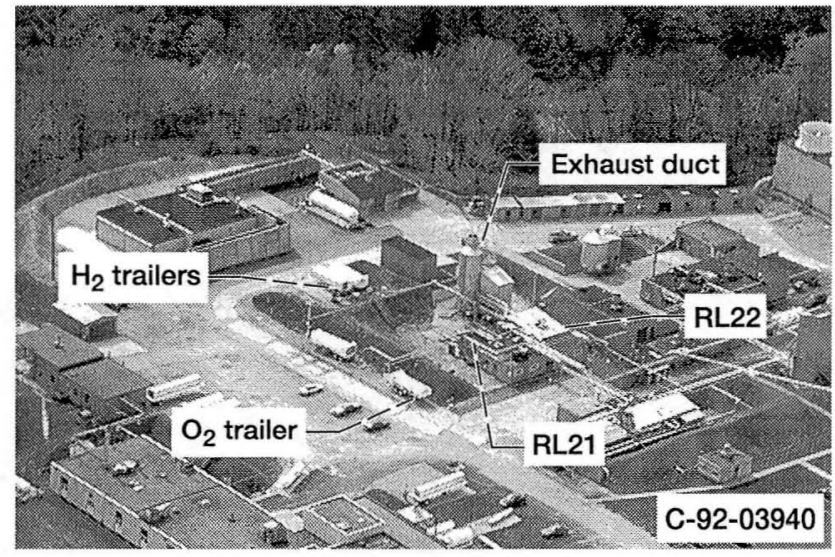

Figure 1.-Aerial view of the Rocket Laboratory.

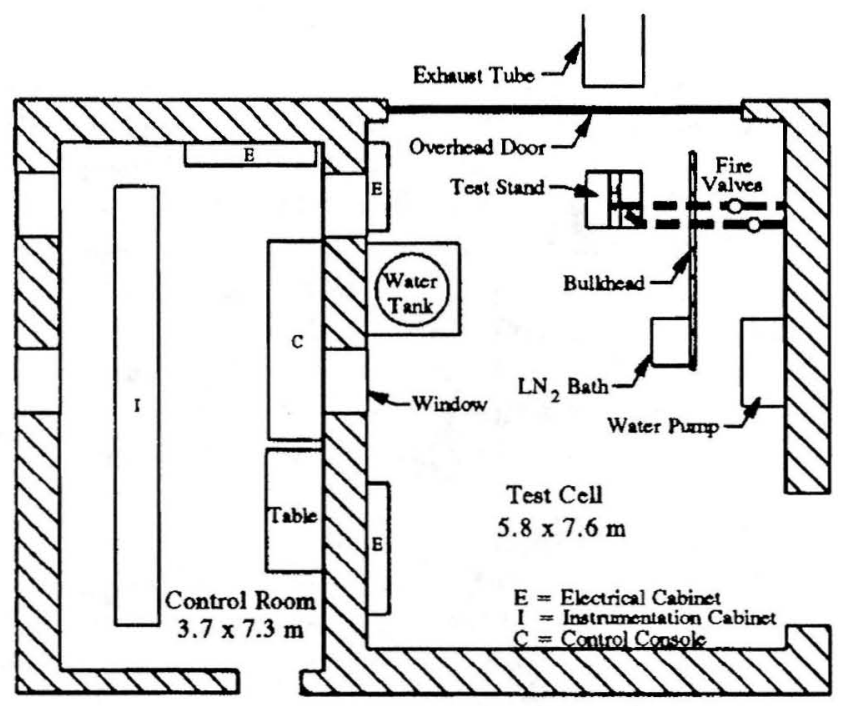

Figure 2.-Test cell layout.

ous exhaust gases when the facility was used for fluorine and other toxic propellants, but now serves as an exhaust duct to vent the combustion gases safely away from the RL22 area.

The dimensions of the test cell and adjacent control room, as well as the locations of some of the important features of the facility, are shown schematically in Fig. 2. The rocket combustor fires horizontally out the overhead door into the exhaust system.

Some of the biggest advantages of testing in RL22 are the high productivity, low operating costs, and quick turnaround times between programs. Depending on the complexity of the program, an average of $20-125$ hot fire tests can be run each test day. For the CMC test program, as many as 210 one second tests have been completed in a single test day.

Due to its small size, RL22 requires only one operations engineer, mechanic, and electronics technician to support a test. Maximum propellant costs are approximately $\$ 1500$ per run day, and are normally significantly less depending on total flow rates being tested. These low costs make RL22 a highly desirable test location.
In addition, turnaround time between programs is extremely short. This turnaround time can be as short as one day for programs using similar hardware configurations. For programs requiring major hardware and instrumentation changes, turnaround times of two weeks are typical.

\section{MECHANICAL SYSTEMS}

Table 1 provides a summary of the maximum capabilities RL22 can deliver, which are described in more detail below.

Table 1.-RL22 Mechanical Capabilities

\begin{tabular}{|l|c|}
\hline \multicolumn{1}{|c|}{ Parameter } & Maximum capability \\
\hline Maximum chamber pressure & $4.14 \mathrm{MPa}(600 \mathrm{psia})$ \\
Mixture ratio & 1 to 20 \\
Maximum $\mathrm{O}_{2}$ flowrate & $1.81 \mathrm{~kg} / \mathrm{sec}\left(4.0 \mathrm{lb}_{\mathrm{m}} / \mathrm{sec}\right)$ \\
Maximum $\mathrm{H}_{2}$ flowrate & $0.91 \mathrm{~kg} / \mathrm{sec}\left(2.0 \mathrm{lb}_{\mathrm{m}} / \mathrm{sec}\right)$ \\
Maximum thrust & $4.45 \mathrm{kN}(1000 \mathrm{lb} \mathrm{f})$ \\
Maximum test duration & 30 to $60 \mathrm{sec}$ \\
Maximum $\mathrm{H}_{2}$ coolant flowrate & $0.11 \mathrm{~kg} / \mathrm{sec}\left(0.25 \mathrm{lb}_{\mathrm{m}} / \mathrm{sec}\right)$ \\
$\mathrm{H}_{2}$ coolant temperature & $\mathrm{Ambient} \mathrm{to} 83 \mathrm{~K}\left(150^{\circ} \mathrm{R}\right)$ \\
Maximum high pressure water & $379 \mathrm{lpm}(100 \mathrm{gpm})$ \\
coolant flowrate & $8.27 \mathrm{MPa}(1200 \mathrm{psia})$ \\
Maximum high pressure water & \\
coolant pressure & \\
\hline
\end{tabular}

\section{Propellant Systems}

RL22 utilizes gaseous $\mathrm{H}_{2}$ and $\mathrm{O}_{2}$ for both ignition and main combustion. The propellants are supplied by tube trailers at $16.5 \mathrm{MPag}$ (2400 psig), containing 1.98 million standard liters $(70,000 \mathrm{SCF})$ of $\mathrm{H}_{2}$ and 1.4 million standard liters $(50,000 \mathrm{SCF})$ of $\mathrm{O}_{2}$. Figure 3 shows a simplified schematic of the $\mathrm{H}_{2}$ main propellant and ignition systems. The design of the $\mathrm{O}_{2}$ system is virtually identical, except the extra lines for the burn-off torches and coolant system are omitted. Three $\mathrm{H}_{2} /$ air burn-off torches, one at the combustor exit and two in the exhaust duct, are used to combust any excess $\mathrm{H}_{2}$ from the main combustion.

The propellant supplies split into main and ignition paths, both of which utilize dome loaded pressure regulators to deliver a constant pressure to a critical venturi or orifice. This supply pressure and the inlet temperature determine the mass flow rate delivered to the main combustion chamber or the igniter. A spark torch igniter ${ }^{8}$ is used to provide consistent ignition of the engine.

For the main combustion chamber, the regulated supply pressures for the two propellants are varied to deliver a wide spectrum of total flow rates and mixture ratios (the mixture ratio, or $\mathrm{O} / \mathrm{F}$, is defined as the $\mathrm{O}_{2} / \mathrm{H}_{2}$ mass flow rate ratio). Mixture ratios from 1.0 to 20.0 have been tested in RL22, and higher O/F's can be provided if required. A maximum chamber pressure of 4.1 MPag (600 psig) can be delivered. The 


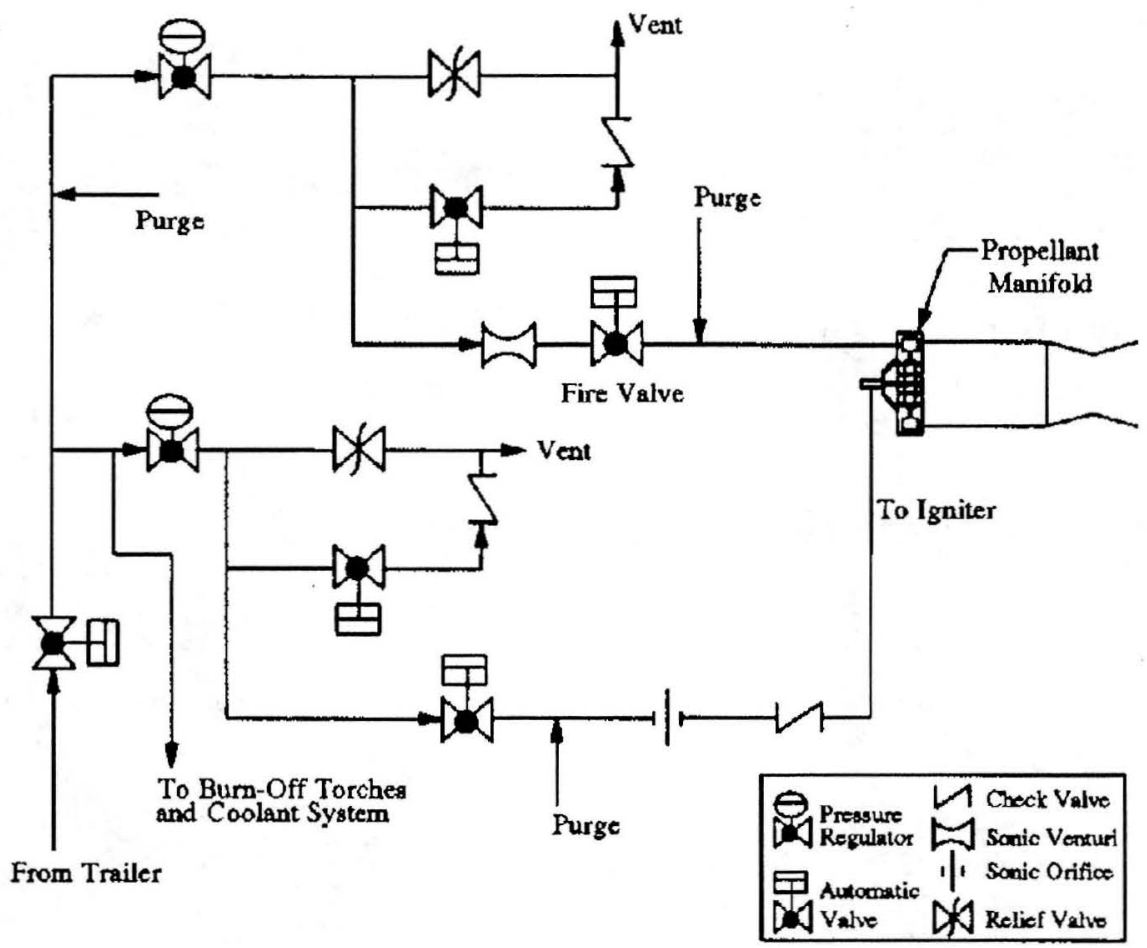

Figure 3.-Simplified hydrogen system schematic.

maximum mass flow rates which can be delivered are $0.91 \mathrm{~kg} /$ $\mathrm{sec}\left(2.0 \mathrm{lb}_{\mathrm{m}} / \mathrm{sec}\right)$ of $\mathrm{H}_{2}$ and $1.81 \mathrm{~kg} / \mathrm{sec}\left(4.0 \mathrm{lb}_{\mathrm{m}} / \mathrm{sec}\right)$ of $\mathrm{O}_{2}$. The maximum test durations listed in Table 1 are dependent on the hardware and operating conditions being tested. Testing with mass flow rates lower than those typically used with existing RL22 hardware could provide longer run durations than those listed.

\section{Hydrogen Coolant System}

The $\mathrm{H}_{2}$ coolant system is used to cool test specimens during testing. $\mathrm{H}_{2}$ coolant is chilled to temperatures as low as $83 \mathrm{~K}\left(150^{\circ} \mathrm{R}\right)$ by passing the coolant through coils submerged in a liquid nitrogen bath. Maximum pressures of $10.34 \mathrm{MPag}$ (1500 psig) can be delivered to the test specimen, at a maximum flow rate of $0.11 \mathrm{~kg} / \mathrm{sec}\left(0.25 \mathrm{lb}_{\mathrm{m}} / \mathrm{sec}\right)$. Depending on the test conditions, the low coolant supply temperature can be maintained for as long as ten seconds before it begins increasing. The coolant system can be reconfigured in different ways to provide the flow parameters needed by the hardware to be tested. Nitrogen gas $\left(\mathrm{GN}_{2}\right)$ can also be supplied as a coolant using this system.

\section{Purge and Water Coolant Systems}

Inert gas purges and water cooling systems are used to provide smooth and safe operation of the rocket engine. $\mathrm{GN}_{2}$ is used extensively throughout the test cell for a number of purposes, including purging lines, loading regulators, actuat- ing valves, driving the high pressure water system, and cooling test specimens.

The $\mathrm{GN}_{2}$ is obtained from a central Rocket Lab source at approximately $15.5 \mathrm{MPag}$ (2250 psig), and is supplied to the purges and components at different regulated pressures depending on the application. The panels of components used to route the $\mathrm{GN}_{2}$ throughout RL22 are shown in Fig. 4.

Two separate water cooling systems are used to keep the engine and test specimen holders cooled during testing. The first is a low pressure system, consisting of a single pump used to cool the igniter and chamber spoolpiece of the engine. This

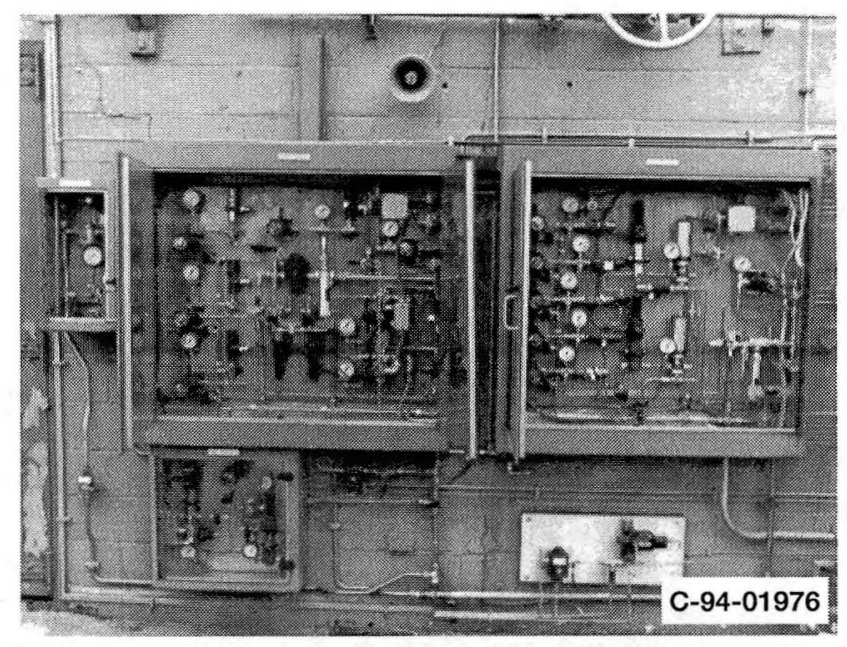

Figure 4.-Nitrogen supply panels. 


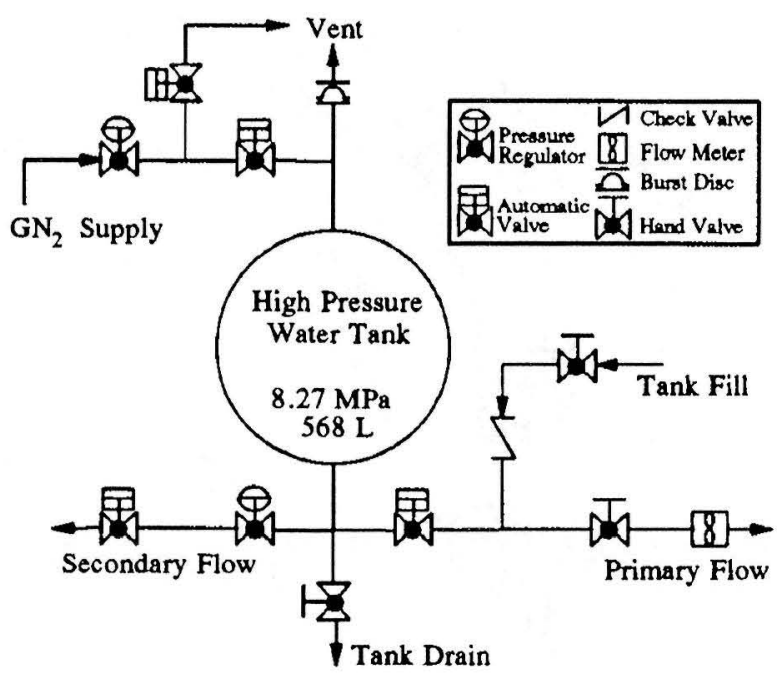

Figure 5.-High pressure water system.

pump delivers a nominal flow of $492 \mathrm{lpm}(130 \mathrm{gpm})$ at 0.6 MPag (90 psig), using domestic water. Low flow rate and pressure aborts are used to automatically stop a test if the water flowing through the system is insufficient to cool the engine during the hot fire. After cooling the engine, the water is routed into a scrubber cooling manifold to provide cooling of the exhaust tube and combustion exhaust gases.

The second water system in RL22 is a high pressure system shown schematically in Fig. 5. This system is divided into a primary system, which is used to cool engine hardware such as the C-D nozzle, and a secondary system, which is used for test specimen holders or water cooled instrumentation such as heat flux gages.

The core of the system is a 568 liter (150 gal.) high pressure tank located inside RL22. The tank is pressurized with $\mathrm{GN}_{2}$ to provide maximum flow rates and pressures of 379 lpm (100 gpm) and $8.27 \mathrm{MPag}$ (1200 psig). The flow rates in the secondary path are typically much lower than the primary path, with a maximum flow of approximately $75.7 \mathrm{lpm}(20$ $\mathrm{gpm})$. Both water paths are synchronized with the rocket firing using a programmable logic controller.

\section{ELECTRONIC SYSTEMS}

\section{Facility Controls}

Since the operation of a rocket combustor requires rapid, precise, and consistent valve operation, a programmable logic controller (PLC) is used to actuate the valves, control the run duration and number of pulses, and abort the firing if a problem occurs. Figure 6 shows the instrumentation racks on the left side of the control room, which house the PLC, abort system, amplifiers, signal conditioners, patchboard, and strip chart recorder.

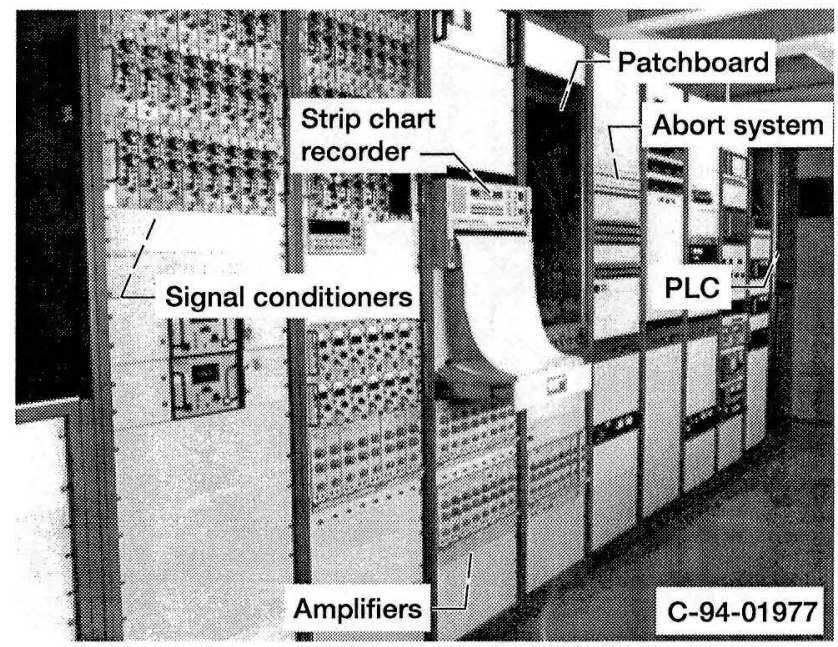

Figure 6.-Control room instrument racks and PLC.

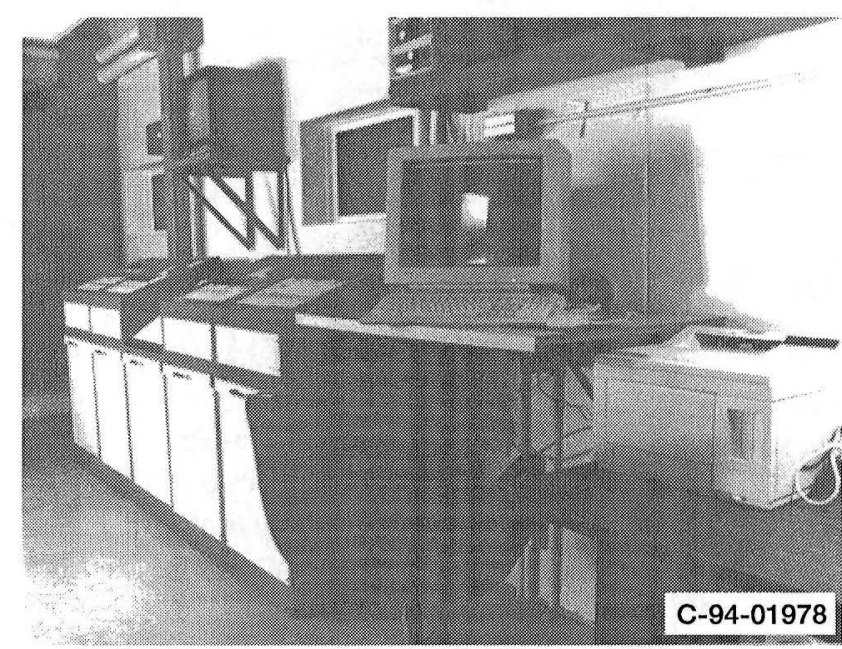

Figure 7.-Control room consoles.

The abort system is used to automatically stop the firing in the event of a facility or hardware problem, and a separate manual abort is available for the operator to abort the test. Ten different automatic aborts are available, with the majority of them used for facility or propellant system parameters.

Before the PLC can be used to start a test firing, all the regulator pressures for propellant flow, coolant flow, and purges must be set manually using the control consoles pictured in Fig. 7. These consoles contain push buttons for the remotely operated valves and regulators, panel meters for monitoring critical parameters, and the manual abort switch. The consoles are the main operator interface with the facility, allowing the operator to be sure everything is ready before turning control over to the PLC.

\section{Instrumentation}

Thermocouples (TC's), pressure transducers, and flow meters are the main instruments used for most tests in RL22. 
Amplifiers and signal conditioners are used to amplify low voltage signals and provide power to the transducers. Each test day the instruments are checked out by zero and percentage of full scale calibration to ensure that the transducers are providing accurate signals.

For temperature measurement, type K, R, and ETC's are typically used, measuring temperatures between $-196^{\circ} \mathrm{C}$ and $1371^{\circ} \mathrm{C}\left(-320^{\circ} \mathrm{F}\right.$ and $\left.2500^{\circ} \mathrm{F}\right)$. The TC's are connected to reference ovens at $66^{\circ} \mathrm{C}\left(150^{\circ} \mathrm{F}\right)$ and then to the instrument patchboard. For pressure measurement, strain gage type pressure transducers with a wide variety of pressure ranges are used. Gaseous flow rates are calculated using calibrated sonic venturies and orifices, which use upstream pressure and temperature measurements to provide a gas flow rate. Different venturies and orifices can be installed to measure a wide range of flow rates. Water flow rates are measured using turbine flow meters. For special requirements, different instrumentation can be used depending on program needs.

\section{Data Acquisition Systems}

The data gathered by the different instruments serves two purposes: research data and data for facility operation and monitoring. To handle the data, four different data collection systems are used in RL22. These include the high speed system, low speed system, strip chart recorder, and visual data recording system.

The high speed data system, called TRADAR(TRAnsient Data Acquisition and Recording), records all of the research data and many of the facility parameters, and passes them on to a VAX cluster located in the central NASA LeRC computer building. Data reduction programs on the VAX convert the data into engineering units, perform calculations, and output the data in a user-defined format.

The TRADAR system takes data from 99 channels at the rate of 100 samples per second per channel. The data for each output channel is averaged every ten readings and the final output lists a value every tenth of a second. Raw, unaveraged data can be obtained if desired. The TRADAR system is accessed from the control room using an $\mathrm{x}$-windows system terminal, which is shown in Fig. 7.

Facility operation and monitoring parameters which are not sent to TRADAR, as well as some important duplicates, are sent to the low speed data system, which has the capability to display 32 channels of data and update them once every one or two seconds. This information is displayed on a television monitor above the control panel.

In addition to high speed recording of the rocket engine data, the performance of the rocket engine is monitored using a high speed digital strip chart recorder. Pressure traces from various transducers such as igniter pressure and chamber pressure are studied to make sure the engine is performing properly during each firing. The strip chart recorder can display up to 16 channels of data, which are recorded as analog differential input signals digitized at a rate of 200 kilosamples per second per channel, with a bandwidth of $20 \mathrm{MHz}$. The high speed capability of the recorder, along with its data capture capability, make it useful for limited acquisition of high frequency data.

Many times the most important data from a test will be visual images of how a test specimen held up to the rocket firing. The visual data recording system in RL22 utilizes a conventional color video camera and VHS recorder, $35 \mathrm{~mm}$ still photography, and 400 frame per second film cameras. The $35 \mathrm{~mm}$ and film cameras are synchronized with the firing using the PLC, and are generally used with zoom lenses to provide close-ups of the test specimen during firing. When combined, the three cameras provide comprehensive coverage of a test program. If additional documentation of a test is required, the NASA video group can be used to provide broadcast quality documentation of a test program.9,10

\section{TEST HARDWARE}

While the test cell can be used with virtually any hardware designed to utilize the cell's mechanical capabilities, one general configuration has been used for all the thermal shock and hot gas testing. The thermal shock test rig (TSTR) hardware has a modular design with a square combustion chamber cross section. The design consists of an injector, igniter, chamber spoolpiece, and converging-diverging (C-D) nozzle. As shown in the hardware schematic, Fig. 8, all of the hardware is water cooled except the injector. Figure 9 shows a photograph of the hardware in an exploded view.

The main propellants first pass through the injector, which consists of a propellant manifold and faceplate. The $\mathrm{H}_{2}$ enters the chamber through the faceplate, which consists of either a large number of small orifices or a porous mesh, depending on the injector. The $\mathrm{H}_{2}$ passing through the faceplate keeps the entire face cool. The $\mathrm{O}_{2}$ enters the chamber through 69 tubes passing through the faceplate. Injectors with different faceplates and oxygen tube sizes are used to provide the entire range of operating conditions of the engine.

After injection, the propellants are ignited and enter the combustion chamber. The igniter piece, which makes up the beginning of the combustion chamber, is a water cooled copper ring that houses the spark-torch igniter. The $0.06 \times 0.06$ $\mathrm{m}(2.3 \times 2.3 \mathrm{in}$.) by $0.15 \mathrm{~m}(6.0 \mathrm{in}$.) long chamber spoolpiece is also water cooled, with a copper inner liner and nickel outer wall. The final component of the hardware is the water cooled C-D nozzle, which provides an expansion area ratio of approximately 1.85 . 


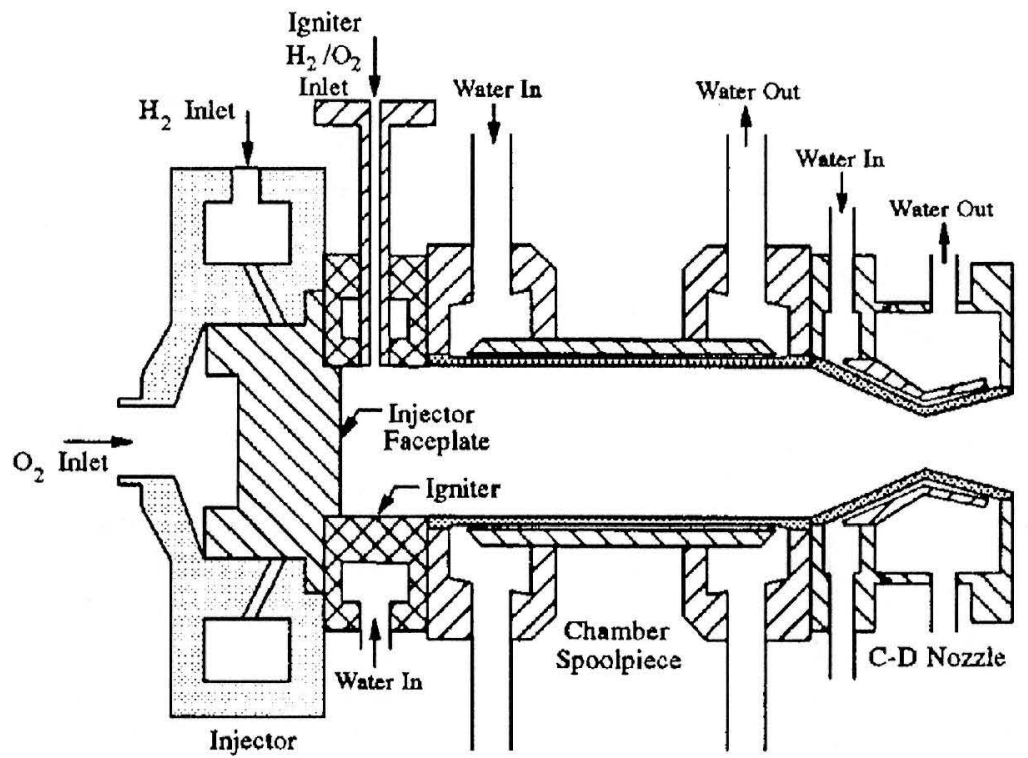

Figure 8.-Schematic of thermal shock test hardware.

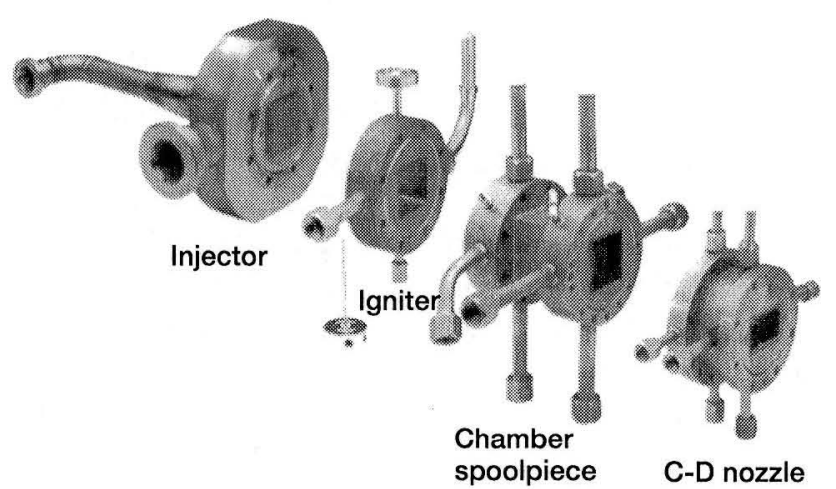

Figure 9.-Thermal shock test hardware.

In addition to the engine hardware, sample holders are used to hold test specimens in the rocket exhaust. These are typically constructed separately for each research program, but existing holders can be used for samples similar to those previously tested, such as flat bars, circular rods, or leading edge shapes.

\section{CONCLUSION}

Test cell 22 of the NASA Lewis Research Center Rocket Laboratory is a versatile facility capable of supporting many different types of research programs, including materials, structures, and rocket propulsion research. The mechanical and electronic capabilities and the test hardware described in this paper have enabled the facility to carry heavy workloads of diverse programs over the years. The flexible nature of the facility, high data rates, and quick turnaround times between programs make RL22 a highly productive, workhorse test facility. This productivity, combined with the low overhead and operating costs associated with the facility, make RL22 an extremely attractive test location.

\section{ACKNOWLEDGMENTS}

This work was performed at the NASA Lewis Research Center under Contract NAS3-21786. The author would like to thank Matt Melis, Andy Eckel, Fred Calfo, Paul Molnar, Bill Furfaro, and the outstanding crew at the Rocket Lab who are too numerous to mention.

\section{REFERENCES}

1. Zoeckler, J.G., Green, J.M., and Raitano, P., "A New Facility for Advanced Rocket Propulsion Research", AIAA-93-1859, June 1993.

2. Linne, D.L., Roncace, J., and Groth, M.F., "Mars In Situ Propellants: Carbon Monoxide and Oxygen Ignition Experiments", AIAA-90-1894, July 1990.

3. Galecki, D.L., "Ignition and Combustion of Metallized Propellants”, AIAA-89-2883, July 1989.

4. Arrington, L.A. and Schneider, S.J., "Low Thrust Rocket Test Facility”, AIAA-90-2503, July 1990.

5. Herbell, T.P. and Eckel, A.J., "Ceramic Matrix Composites for Rocket Engine Turbine Applications", Transactions of the ASME, Vol. 115, January 1993.

6. Martin, L.C., "Testing of Thin Film Thermocouples in RocketEngine Environments", Proceedings of the NASA 
Marshall Space Flight Center Advanced Earth-to-Orbit Propulsion Technology Conference, May 1994.

7. Gladden, H.J., and Melis, M.E., "Hypersonic Engine Component Experiments in a High Heat Flux, Supersonic Flow Environment", NASA TM 106273, July 1993.

8. Repas, G.A., "Hydrogen-Oxygen Torch Ignitor", NASA TM 106493, March 1994.

9. Melis, M.E., Project Manager, Produced by the NASA Lewis Research Center Video \& Motion Picture Group, "NASP Engine Seals Tests", video number 92-178-03, April 1993.

10. Melis, M.E., Project Manager, Produced by the NASA Lewis Research Center Video \& Motion Picture Group, "Actively Cooled Leading Edges - A Component Test for the National Aerospace Plane Program", video number 92-208, April 1993. 
Public reporting burden for this collection of information is estimated to average 1 hour per response, including the time for reviewing instructions, searching existing data sources, gathering and maintaining the data needed, and completing and reviewing the collection of information. Send comments regarding this burden estimate or any other aspect of this collection of information, including suggestions for reducing this burden, to Washington Headquarters Services, Directorate for Information Operations and Reports, 1215 Jefferson Davis Highway, Suite 1204, Arlington, VA 22202-4302, and to the Office of Management and Budget, Paperwork Reduction Project (0704-0188), Washington, DC 20503.

\begin{tabular}{|l|l|r|}
\hline 1. AGENCY USE ONLY (Leave blank) & $\begin{array}{r}\text { 2. REPORT DATE } \\
\text { June } 1994\end{array}$ & $\begin{array}{r}\text { 3. REPORT TYPE AND DATES COVERED } \\
\text { Final Contractor Report }\end{array}$ \\
\hline
\end{tabular}

4. TITLE AND SUBTITLE

5. FUNDING NUMBERS

A Versatile Rocket Engine Hot Gas Facility

\section{AUTHOR(S)}

James M. Green
WU-584-03-11

C-NAS3-25266

8. Performing organization REPORT NUMBER

E-8900

Inc.

Engineering Services Division

2001 Aerospace Parkway

Brook Park, Ohio 44142

9. SPONSORING/MONITORING AGENCY NAME(S) AND ADDRESS(ES)

National Aeronautics and Space Administration

Lewis Research Center

Cleveland, Ohio 44135-3191

AIAA-94-2487

\section{SUPPLEMENTARY NOTES}

Prepared for the AIAA Aerospace Ground Testing Conference, Colorado Springs, Colorado, June 20-23, 1994. Work funded by

NASA Contract NAS3-25266 with Sverdrup Technology, Inc., Lewis Research Center Group. Project Manager, Ronald R.

Roskilly, Aerospace Technology Facilities Division, NASA Lewis Research Center, organization code 5710, (216) 433-7551.

12a. DISTRIBUTION/AVAILABILITY STATEMENT

12b. DISTRIBUTION CODE

Unclassified - Unlimited

Subject Category 14

\section{ABSTRACT (Maximum 200 words)}

The capabilities of a versatile rocket engine facility, located in the Rocket Laboratory at the NASA Lewis research Center, are presented. The gaseous hydrogen/oxygen facility can be used for thermal shock and hot gas testing of materials and structures as well as rocket propulsion testing. Testing over a wide range of operating conditions in both fuel and oxygen rich regimes can be conducted, with cooled or uncooled test specimens. The size and location of the test cell provide the ability to conduct large amounts of testing in short time periods with rapid turnaround between programs.

\section{SUBJECT TERMS}

Rocket testing; Rocket propulsion; Ground testing; Test facilities; Hot gas testing; Thermal shock testing

\begin{tabular}{|c|c|c|}
\hline $\begin{array}{c}\text { 17. SECURITY CLASSIFICATION } \\
\text { OF REPORT } \\
\text { Unclassified }\end{array}$ & $\begin{array}{c}\text { 18. SECURITY CLASSIFICATION } \\
\text { OF THIS PAGE } \\
\text { Unclassified }\end{array}$ & $\begin{array}{c}\text { 19. SECURITY CLASSIFICATION } \\
\text { OF ABSTRACT } \\
\text { Unclassified }\end{array}$ \\
\hline
\end{tabular}

